\title{
Two New Cyclopentenone Derivatives and a New Cyclooctadienone Derivative from Erigeron annuus (L.) Pers., Erigeron philadelphicus L., and Erigeron sumatrensis RETZ.
}

\author{
Takeyoshi IıJima, Yasunori YaorTA, and Masao KIKUCHI* \\ Tohoku Pharmaceutical University; 4-4-1 Komatsushima, Aoba-ku, Sendai, Miyagi 981-8558, Japan. \\ Received March 6, 2003; accepted March 30, 2003
}

\begin{abstract}
Two new cyclopentenone derivatives, erigerenones $A(1)$ and $B$ (2), and a new cyclooctadienone derivative, erigerenone C (3), were isolated from the aerial parts of Erigeron philadelphicus L. Compound 2 was also isolated from the aerial parts of Erigeron annuus (L.) Pers. and Erigeron sumatrensis Retz. The structures of 1-3 were elucidated on the basis of their spectral data.
\end{abstract}

Key words Erigeron annuus; Erigeron philadelphicus; Erigeron sumatrensis; Compositae; cyclopentenone derivative; cyclooctadienone derivative

The genus Erigeron is a common group of Compositae plants, and Erigeron annuus (L.) Pers. (himejyon in Japanese), Erigeron philadelphicus L. (harujion in Japanese) and Erigeron sumatrensis RETz. (oarechinogiku in Japanese) are now, as naturalized weeds, widely distributed throughout urban and rural areas of Japan. ${ }^{1)}$ Among these, E. annuus has been used as an hypoglycemic drug in China. ${ }^{2)}$ The constituents of E. annuus, E. philadelphicus, and E. sumatrensis have been previously investigated and shown to contain monoterpenoids, ${ }^{3)}$ sesquiterpenoids, ${ }^{3)}$ diterpenoid, ${ }^{4)}$ polyacetylenic compounds, ${ }^{5)}$ and $\gamma$-pyrone derivatives. ${ }^{1)}$ Recently we reported the isolation and structural elucidation of norisoprenoids, ${ }^{6}{ }^{6}$ sesquiterpenoids, ${ }^{7)}$ diterpenoids, ${ }^{7)}$ triterpenoids, ${ }^{8)}$ and sterols ${ }^{8)}$ from the aerial parts and roots of $E$. annuus, $E$. philadelphicus, and E. sumatrensis. As part of our continuing study of the constituents of the genus Erigeron plants, we now report the isolation and structural elucidation of two new cyclopentenone derivatives, erigerenons A (1) and B (2), and a new cyclooctadienone derivative, erigerenone $\mathrm{C}$ (3), from the aerial parts of E. annuus, E. philadelphicus, and $E$. sumatrensis.

Compound 1 was isolated as a colorless oil, $[\alpha]_{\mathrm{D}}+7.3^{\circ}$. The molecular formula was determined to be $\mathrm{C}_{12} \mathrm{H}_{16} \mathrm{O}_{4}$ by high-resolution (HR)-electron ionization (EI)-MS. The IR spectrum showed the presence of ester $\left(1735 \mathrm{~cm}^{-1}\right)$ and $\alpha, \beta$ unsaturated ketone $\left(1691,1596 \mathrm{~cm}^{-1}\right)$ functionalities. The UV spectrum also suggested the presence of an $\alpha, \beta$-unsaturated ketone $\left(\lambda_{\max }=237 \mathrm{~nm}\right)$. The ${ }^{1} \mathrm{H}$ - (Table 1$)$ and ${ }^{13} \mathrm{C}$ NMR spectra (Table 2), obtained with the aid of distortionless enhancement by polarization transfer (DEPT) and ${ }^{1} \mathrm{H}$-detected heteronuclear multiple quantum coherence (HMQC) spectra, showed signals due to a methyl $\left[\delta_{\mathrm{H}} 1.70\left(3 \mathrm{H}, \mathrm{H}_{3}-\right.\right.$ $\left.10) ; \delta_{\mathrm{C}} 13.1(\mathrm{C}-10)\right]$, a methylene $\left[\delta_{\mathrm{H}} 2.58\left(1 \mathrm{H}, \mathrm{H}_{\mathrm{a}}-2\right), 2.77\right.$ $\left.\left(1 \mathrm{H}, \mathrm{H}_{\mathrm{b}}-2\right) ; \delta_{\mathrm{C}} 33.8(\mathrm{C}-2)\right]$, two methines $\left[\delta_{\mathrm{H}} 2.56(1 \mathrm{H}, \mathrm{H}-3)\right.$, $\left.3.68(1 \mathrm{H}, \mathrm{H}-7) ; \delta_{\mathrm{C}} 44.8(\mathrm{C}-7), 49.9(\mathrm{C}-3)\right]$, two methoxyl groups $\left[\delta_{\mathrm{H}} 3.67\left(3 \mathrm{H}, \mathrm{CH}_{3} \mathrm{O}-1\right), 3.84\left(3 \mathrm{H}, \mathrm{CH}_{3} \mathrm{O}-6\right) ; \delta_{\mathrm{C}} 51.7\right.$ $\left.\left(\mathrm{CH}_{3} \mathrm{O}-1\right), 59.0\left(\mathrm{CH}_{3} \mathrm{O}-6\right)\right]$, a trisubstituted double bond $\left[\delta_{\mathrm{H}}\right.$ $5.32(1 \mathrm{H}, \mathrm{H}-5) ; \delta_{\mathrm{C}} 102.9(\mathrm{C}-5), 190.3$ (C-6)], a disubstituted double bond $\left[\delta_{\mathrm{H}} 5.24(1 \mathrm{H}, \mathrm{H}-8), 5.74(1 \mathrm{H}, \mathrm{H}-9) ; \delta_{\mathrm{C}} 127.6\right.$ $(\mathrm{C}-8), 128.5(\mathrm{C}-9)]$, and two carbonyl carbons $\left[\delta_{\mathrm{C}} 172.3(\mathrm{C}-\right.$ 1), 204.2 (C-4)]. The gross structure of 1 was elucidated by analyses of two-dimensional (2D) NMR data including ${ }^{1} \mathrm{H}-{ }^{1} \mathrm{H}$ shift correlation spectroscopy $\left({ }^{1} \mathrm{H}-{ }^{1} \mathrm{H} \mathrm{COSY}\right)$ and ${ }^{1} \mathrm{H}-$ detected heteronuclear multiple bond connectivity (HMBC) spectra (Fig. 1). The ${ }^{1} \mathrm{H}-{ }^{1} \mathrm{H}$ COSY spectrum of $\mathbf{1}$ implied connectivities for $\mathrm{H}_{2}-2-\mathrm{H}-3, \mathrm{H}-3-\mathrm{H}-7, \mathrm{H}-7-\mathrm{H}-8, \mathrm{H}-8-$ $\mathrm{H}-9$, and $\mathrm{H}-9-\mathrm{H}_{3}-10$. Interpretation of the $\mathrm{HMBC}$ spectrum revealed correlations from $\mathrm{H}_{2}-2$ to $\mathrm{C}-1$ and $\mathrm{C}-4 ; \mathrm{H}-5$ to $\mathrm{C}-3$ and $\mathrm{C}-7$; $\mathrm{H}-7$ to $\mathrm{C}-6$; $\mathrm{CH}_{3} \mathrm{O}-1$ to $\mathrm{C}-1$; and $\mathrm{CH}_{3} \mathrm{O}-6$ to $\mathrm{C}-6$. Thus the gross structure of $\mathbf{1}$ was deduced to be as shown in Fig. 1. The relative stereochemistry at C-3 and C-7 was established by comparing the proton coupling constant between H-3 and H-7 with analogous couplings observed for other cyclopentenones. $^{9,10)}$ In cyclopentene rings, a vicinal coupling constant of $5-6 \mathrm{~Hz}$ normally indicates a cis relationship, while a coupling constant of $c a$. $2 \mathrm{~Hz}$ suggests a trans relationship. ${ }^{11)}$ These observations have been extended to cyclopentenone rings and a similar correlation has been observed. ${ }^{9,10)}$ Thus, in the case of $\mathbf{1}$, the small coupling constant of $2.2 \mathrm{~Hz}$ is suggestive of a trans relationship between $\mathrm{H}-3$ and H-7. The geometry of the $\Delta^{8}$-double bond was deduced to be $Z$ from ${ }^{1} \mathrm{H}-{ }^{1} \mathrm{H}$ coupling constant $(J=11.0 \mathrm{~Hz})$ between $\mathrm{H}-8$ and H-9. On the basis of the above data, the structure of 1 was represented as shown in the formula.

Compound 2 was isolated as a colorless oil, $[\alpha]_{\mathrm{D}}+7.9^{\circ}$. The molecular formula was determined to be $\mathrm{C}_{12} \mathrm{H}_{18} \mathrm{O}_{4}$ by HR-EI-MS. The ${ }^{1} \mathrm{H}$ - and ${ }^{13} \mathrm{C}-\mathrm{NMR}$ spectra of 2 resembled those of 1, except for the presence of two methylene groups $\left[\delta_{\mathrm{H}} 1.51\left(1 \mathrm{H}, \mathrm{H}_{\mathrm{a}}-8\right), 1.75\left(1 \mathrm{H}, \mathrm{H}_{\mathrm{b}}-8\right), 1.33\left(2 \mathrm{H}, \mathrm{H}_{2}-9\right) ; \delta_{\mathrm{C}}\right.$ 19.5 (C-9), 33.8 (C-8)] instead of a disubstituted double bond in $\mathbf{1}$. The molecular formula of $\mathbf{2}$ suggested that $\mathbf{2}$ was a dihydro derivative of $\mathbf{1}$. The ${ }^{1} \mathrm{H}-{ }^{1} \mathrm{H}$ COSY spectrum of $\mathbf{2}$ implied
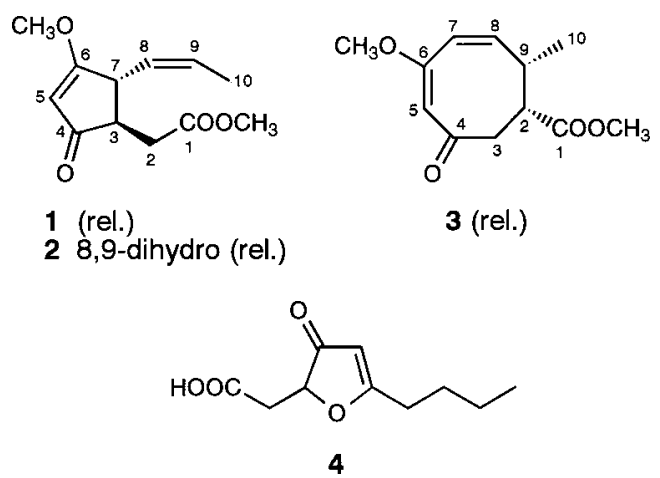

Chart 1 
Table 1. ${ }^{1} \mathrm{H}-\mathrm{NMR}$ Chemical Shifts of Compounds $\mathbf{1}-\mathbf{3} \quad\left(\mathrm{CDCl}_{3}\right.$, $400 \mathrm{MHz})$

\begin{tabular}{clll}
\hline \hline Proton & \multicolumn{1}{c}{$\mathbf{1}^{a)}$} & \multicolumn{1}{c}{$\mathbf{2}$} & \multicolumn{1}{c}{$\mathbf{3}$} \\
\hline 2 & $\begin{array}{l}\text { a } 2.58 \mathrm{dd} \\
(20.5,8.1)^{b)}\end{array}$ & $\begin{array}{l}\text { a } 2.53 \mathrm{dd} \\
(20.2,8.1)\end{array}$ & $\begin{array}{l}3.16 \mathrm{ddd} \\
(13.2,5.6,3.9)\end{array}$ \\
& $\mathrm{b} 2.77 \mathrm{dd}$ & $\mathrm{b} 27.5 \mathrm{dd}$ & \\
& $(20.5,8.8)$ & $(20.2,8.8)$ & \\
3 & $2.56 \mathrm{~m}$ & $2.51 \mathrm{~m}$ & $\alpha 3.30 \mathrm{dd}$ \\
& & & $(13.2,11.0)$ \\
& & & $\beta 2.40 \mathrm{ddd}$ \\
5 & $5.32 \mathrm{~d}(1.1)$ & $5.27 \mathrm{~d}(0.7)$ & $(11.0,3.9,1.5)$ \\
7 & $3.68 \mathrm{ddd}$ & $2.64 \mathrm{ddd}$ & $6.19 \mathrm{dd}$ \\
& $(9.9,2.2,1.1)$ & $(5.4,5.1,2.4)$ & $(11.7,0.7)$ \\
8 & $5.24 \mathrm{ddq}$ & $\mathrm{a} 1.51 \mathrm{~m}$ & $6.16 \mathrm{dd}$ \\
& $(11.0,9.9,1.8)$ & $\mathrm{b} 1.75 \mathrm{~m}$ & $(12.7,11.7)$ \\
9 & $5.74 \mathrm{dqd}$ & $1.33^{c)} \mathrm{m}$ & $2.92 \mathrm{~m}$ \\
& $(11.0,7.0,1.1)$ & & \\
10 & $1.70 \mathrm{dd}$ & $0.93 \mathrm{t}(7.3)$ & $1.11 \mathrm{~d}(6.6)$ \\
& $(7.0,1.8)$ & & \\
$\mathrm{CH}_{3} \mathrm{O}-1$ & $3.67 \mathrm{~s}$ & $3.68 \mathrm{~s}$ & $3.69 \mathrm{~s}$ \\
$\mathrm{CH}_{3} \mathrm{O}-6$ & $3.84 \mathrm{~s}$ & $3.84 \mathrm{~s}$ & $3.66 \mathrm{~s}$ \\
\hline
\end{tabular}

a) Measured at $600 \mathrm{MHz}$. b) Coupling constants $(J$ in $\mathrm{Hz})$ are given in parentheses. c) $2 \mathrm{H}$.

Table 2. ${ }^{13} \mathrm{C}-\mathrm{NMR}$ Chemical Shifts of Compounds $\mathbf{1}-\mathbf{3} \quad\left(\mathrm{CDCl}_{3}\right.$, $100 \mathrm{MHz})$

\begin{tabular}{crrr}
\hline \hline Carbon & $\mathbf{1}^{a)}$ & $\mathbf{2}$ & \multicolumn{1}{c}{$\mathbf{3}$} \\
\hline 1 & 172.3 & 172.4 & 172.8 \\
2 & 33.8 & 35.3 & 54.0 \\
3 & 49.9 & 48.0 & 41.9 \\
4 & 204.2 & 204.9 & 199.9 \\
5 & 102.9 & 102.8 & 107.2 \\
6 & 190.3 & 192.0 & 166.6 \\
7 & 44.8 & 46.3 & 125.4 \\
8 & 127.6 & 33.8 & 145.0 \\
9 & 128.5 & 19.5 & 34.6 \\
10 & 13.1 & 14.2 & 17.6 \\
$\mathrm{CH}_{3} \mathrm{O}-1$ & 51.7 & 51.7 & 51.6 \\
$\mathrm{CH}_{3} \mathrm{O}-6$ & 59.0 & 58.7 & 56.0 \\
\hline
\end{tabular}

a) Measured at $150 \mathrm{MHz}$.

connectivities for $\mathrm{H}-7-\mathrm{H}_{2}-8, \mathrm{H}_{2}-8-\mathrm{H}_{2}-9$, and $\mathrm{H}_{2}-9-\mathrm{H}_{3}-10$. The relative stereochemistry at $\mathrm{C}-3$ and $\mathrm{C}-7$ was deduced to be trans from the ${ }^{1} \mathrm{H}-{ }^{1} \mathrm{H}$ coupling constant $(J=2.4 \mathrm{~Hz})$ between $\mathrm{H}-3$ and H-7. ${ }^{9-11)}$ Thus compound 2 was an 8,9-dihydro derivative of $\mathbf{1}$. From the above data, the structure of $\mathbf{2}$ was represented as shown in the formula.

Compound 3 was isolated as a colorless oil, $[\alpha]_{\mathrm{D}}+4.2^{\circ}$. The molecular formula was determined to be $\mathrm{C}_{12} \mathrm{H}_{16} \mathrm{O}_{4}$ by HR-EI-MS. The IR spectrum showed the presence of ester $\left(1731 \mathrm{~cm}^{-1}\right)$ and $\alpha, \beta-\gamma, \delta$-unsaturated ketone (1627, $1592 \mathrm{~cm}^{-1}$ ) functionalities. The UV spectrum also suggested the presence of an $\alpha, \beta-\gamma, \delta$-unsaturated ketone $\left(\lambda_{\max }=\right.$ $279 \mathrm{~nm})$. The ${ }^{1} \mathrm{H}$ - and ${ }^{13} \mathrm{C}$-NMR spectra showed signals due to a secondary methyl $\left[\delta_{\mathrm{H}} 1.11\left(3 \mathrm{H}, \mathrm{H}_{3}-10\right) ; \delta_{\mathrm{C}} 17.6(\mathrm{C}-10)\right]$, a methylene $\left[\delta_{\mathrm{H}} 2.40\left(1 \mathrm{H}, \mathrm{H}_{\beta}-3\right), 3.30\left(1 \mathrm{H}, \mathrm{H}_{\alpha}-3\right) ; \delta_{\mathrm{C}} 41.9\right.$ $(\mathrm{C}-3)]$, two methines $\left[\delta_{\mathrm{H}} 2.92(1 \mathrm{H}, \mathrm{H}-9), 3.16(1 \mathrm{H}, \mathrm{H}-2) ; \delta_{\mathrm{C}}\right.$ $34.6(\mathrm{C}-9), 54.0(\mathrm{C}-2)]$, two methoxyl groups $\left[\delta_{\mathrm{H}} 3.66(3 \mathrm{H}\right.$, $\left.\mathrm{CH}_{3} \mathrm{O}-6\right), 3.69\left(3 \mathrm{H}, \mathrm{CH}_{3} \mathrm{O}-1\right) ; \delta_{\mathrm{C}} 51.6\left(\mathrm{CH}_{3} \mathrm{O}-1\right), 56.0$ $\left.\left(\mathrm{CH}_{3} \mathrm{O}-6\right)\right]$, a trisubstituted double bond $\left[\delta_{\mathrm{H}} 5.49(1 \mathrm{H}, \mathrm{H}-5)\right.$; $\left.\delta_{\mathrm{C}} 107.2(\mathrm{C}-5), 166.6(\mathrm{C}-6)\right]$, a disubstituted double bond [ $\delta_{\mathrm{H}}$

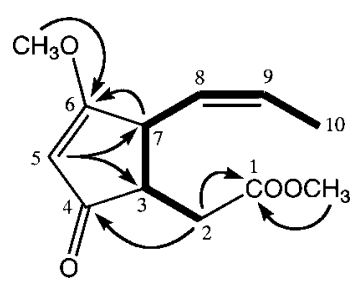

Fig. 1. ${ }^{1} \mathrm{H}-{ }^{1} \mathrm{H}$ COSY (Bold Lines) and HMBC (Arrows) Correlations for

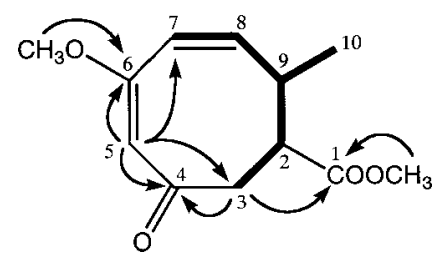

Fig. 2. ${ }^{1} \mathrm{H}-{ }^{1} \mathrm{H}$ COSY (Bold Lines) and HMBC (Arrows) Correlations for 3

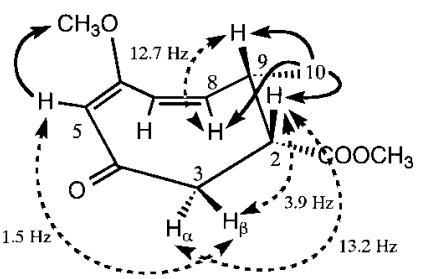

Fig. 3. Selected $J$-Values (Dotted-Line Arrows) and Significant NOEs (Full-Line Arrows) in 3

$6.16(1 \mathrm{H}, \mathrm{H}-8), 6.19(1 \mathrm{H}, \mathrm{H}-7) ; \delta_{\mathrm{C}} 125.4(\mathrm{C}-7), 145.0(\mathrm{C}-$ $8)$, and two carbonyl carbons [ $\left.\delta_{\mathrm{C}} 172.8(\mathrm{C}-1), 199.9(\mathrm{C}-4)\right]$. The gross structure of 3 was elucidated by analyses of $2 \mathrm{D}$ NMR data including ${ }^{1} \mathrm{H}-{ }^{1} \mathrm{H}$ COSY and $\mathrm{HMBC}$ spectra (Fig. 2). The ${ }^{1} \mathrm{H}-{ }^{1} \mathrm{H}$ COSY spectrum of 3 implied connectivities for $\mathrm{H}-2-\mathrm{H}-3, \mathrm{H}-2-\mathrm{H}-9, \mathrm{H}-7-\mathrm{H}-8, \mathrm{H}-8-\mathrm{H}-9$, and $\mathrm{H}-9-$ $\mathrm{H}_{3}-10$. Interpretation of the HMBC spectrum revealed correlations from $\mathrm{H}_{2}-3$ to $\mathrm{C}-1$ and $\mathrm{C}-4$; $\mathrm{H}-5$ to $\mathrm{C}-3, \mathrm{C}-4, \mathrm{C}-6$ and $\mathrm{C}-7$; $\mathrm{CH}_{3} \mathrm{O}-1$ to $\mathrm{C}-1$; and $\mathrm{CH}_{3} \mathrm{O}-6$ to $\mathrm{C}-6$. Thus the gross structure of $\mathbf{3}$ was deduced to be as shown in Fig. 2. The relative stereochemistry at C-2 and C-9 was established as follows (Fig. 3). In the ${ }^{1} \mathrm{H}-\mathrm{NMR}$ spectrum, the long-range coupling observed between $\mathrm{H}_{\beta}-3$ and $\mathrm{H}-5(J=1.5 \mathrm{~Hz})$ indicated that the bonds between them are $\mathrm{W}$-shaped. The magnitude of $J_{2,3 \alpha}=13.2$ and $J_{2,3 \beta}=3.9 \mathrm{~Hz}$ suggested that $\mathrm{H}-2$ and $\mathrm{H}_{\alpha}-3$, $\mathrm{H}-2$ and $\mathrm{H}_{\beta}-3$ were located in anti and gauche arrangements, respectively. Thus the relative stereochemistry at C-2 was determined to be $R^{*}$. The magnitude of $J_{8,9}=12.7 \mathrm{~Hz}$ suggested that $\mathrm{H}-8$ and $\mathrm{H}-9$ were located in an anti arrangement. In the difference nuclear Overhauser effect (NOE) experiments, irradiation at $\delta 1.11\left(\mathrm{H}_{3}-10\right)$ caused NOE enhancement in the signals of the $\mathrm{H}-2, \mathrm{H}-8$, and $\mathrm{H}-9$. The ${ }^{1} \mathrm{H}-{ }^{1} \mathrm{H}$ coupling constant $(J=12.7 \mathrm{~Hz})$ between $\mathrm{H}-8$ and $\mathrm{H}-9$, and the observation of NOE from the $\mathrm{H}_{3}-10$ methyl group to $\mathrm{H}-8$ implied that the relative stereochemistry at C-9 was $S^{*}$. The geometry of the $\Delta^{5}$-double bond was shown to be $E$. Accordingly, irradiation at $\delta 5.49(\mathrm{H}-5)$ caused NOE enhancement in the signal of the $\mathrm{CH}_{3} \mathrm{O}-6$. The $Z$ configuration of the $\Delta^{7}$-double bond was shown by the ${ }^{1} \mathrm{H}-{ }^{1} \mathrm{H}$ coupling constant $(J=11.7 \mathrm{~Hz})$ between 
H-7 and H-8. On the basis of the above data, the structure of $\mathbf{3}$ was represented as shown in the formula.

In conclusion, we described here the isolation and structure elucidation of erigerenones A (1), B (2), and C (3) from the aerial parts of E. annuus, E. philadelphicus, and E. sumatrensis. Although dibenzocyclooctadienone lignans such as steganone ${ }^{12)}$ and benzocyclooctadienone sesquiterpenes such as isoparvifolinone ${ }^{13)}$ are known, compound $\mathbf{3}$ is, to the best of our knowledge, the first example of a naturally occurring cyclooctadienone derivative without the fused phenyl system.

The framework of compounds $\mathbf{1}-\mathbf{3}$ resembles that of (5butyl-3-oxo-2,3-dihydrofuran-2-yl)-acetic acid (4), which was recently isolated from $E$. annuus. ${ }^{14)}$ This implies that compounds 1-4 may be formed by similar biosynthetic processes.

\section{Experimental}

General Procedures Optical rotations were determined using a JASCO DIP-360 digital polarimeter. IR spectra were recorded with a Perkin-Elmer FT-IR 1725X IR spectrophotometer and UV spectra on a Beckman DU-64 spectrophotometer. ${ }^{1} \mathrm{H}$ - and ${ }^{13} \mathrm{C}$-NMR spectra were recorded using JEOL JNM-LA 600 (600 and $150 \mathrm{MHz}$, respectively) and JEOL JNM-LA 400 (400 and $100 \mathrm{MHz}$, respectively) spectrometers. Chemical shifts are given on a $\delta(\mathrm{ppm})$ scale, with tetramethylsilane as an internal standard. The HREI-MS were recorded on a JEOL JMS-DX 303 mass spectrometer. Column chromatography was carried out on Kieselgel 60 (230 - 400 mesh, Merck). Preparative HPLC was carried out on a Tosoh HPLC system (pump, CCPM; detector, RI-8020 and UV-8020) using TSKgel ODS-120T $(7.8 \mathrm{~mm}$ i.d. $\times 30 \mathrm{~cm}$ ) column (Tosoh).

Plant Material The aerial parts of E. annuus were collected in Sendai City, Miyagi Prefecture, Japan, in July 2001; those of E. philadelphicus in Sendai City in April 2002; and those of E. sumatrensis in Sendai City in October 2000.

Extraction and Isolation E. annuus: The aerial parts of $E$. annuus $(5.3 \mathrm{~kg})$ were extracted with $\mathrm{MeOH}$ at room temperature for 2 weeks. The $\mathrm{MeOH}$ extract was concentrated under reduced pressure and the residue was suspended in a small excess of water. This suspension was extracted with $\mathrm{CHCl}_{3}$. The $\mathrm{CHCl}_{3}$-soluble fraction was concentrated under reduced pressure to afford a residue $(79.4 \mathrm{~g})$. A part of this residue $(67.0 \mathrm{~g})$ was chromatographed on a silica gel column using hexane-EtOAc $(7: 1-1: 7)$ and $\mathrm{CHCl}_{3}-\mathrm{MeOH}(9: 1-1: 1)$ to afford 62 fractions. Fraction 19 was purified by preparative HPLC [column temperature, $40^{\circ} \mathrm{C}$; mobile phase, $\mathrm{MeOH}-\mathrm{H}_{2} \mathrm{O}$ (1:1); flow rate, $1.5 \mathrm{ml} / \mathrm{min}$; RI detector] to give $2(0.5 \mathrm{mg})$.

E. philadelphicus: The aerial parts of E. philadelphicus $(2.5 \mathrm{~kg})$ were extracted with $\mathrm{MeOH}$ at room temperature for 2 weeks. The $\mathrm{MeOH}$ extract was concentrated under reduced pressure and the residue was suspended in a small excess of water. This suspension was extracted with $\mathrm{CHCl}_{3}$. The $\mathrm{CHCl}_{3}$-soluble fraction was concentrated under reduced pressure to afford a residue $(24.0 \mathrm{~g})$. This residue was chromatographed on a silica gel column using hexanen-EtOAc $(7: 1-1: 7)$ and $\mathrm{CHCl}_{3}-\mathrm{MeOH}(9: 1-1: 1)$ to afford 47 fractions. Fraction 11 was purified by preparative HPLC [column temperature, $40^{\circ} \mathrm{C}$; mobile phase, $\mathrm{MeOH}-\mathrm{H}_{2} \mathrm{O}(1: 1)$; flow rate, $1.5 \mathrm{ml} / \mathrm{min}$; RI detector] to give $3(2.4 \mathrm{mg})$. Fraction 17 was purified by preparative
HPLC [column temperature, $40^{\circ} \mathrm{C}$; mobile phase, $\mathrm{MeOH}-\mathrm{H}_{2} \mathrm{O}(1: 1)$; flow rate, $1.5 \mathrm{ml} / \mathrm{min}$; UV detector, $230 \mathrm{~nm}$ ] to give $\mathbf{1}(1.5 \mathrm{mg})$ and $\mathbf{2}(0.4 \mathrm{mg})$.

E. sumatrensis: The aerial parts of E. sumatrensis $(4.0 \mathrm{~kg})$ were extracted with $\mathrm{MeOH}$ at room temperature for 2 weeks. The $\mathrm{MeOH}$ extract was concentrated under reduced pressure and the residue was suspended in a small excess of water. This suspension was extracted with $\mathrm{CHCl}_{3}$. The $\mathrm{CHCl}_{3}$-soluble fraction was concentrated under reduced pressure to afford a residue $(80.7 \mathrm{~g})$. A part of this residue $(50.0 \mathrm{~g})$ was chromatographed on a silica gel column using hexane-EtOAc $(7: 1-1: 7)$ and $\mathrm{CHCl}_{3}-\mathrm{MeOH}(9: 1-1: 1)$ to afford 60 fractions. Fraction 18 was purified by preparative HPLC [column temperature, $40^{\circ} \mathrm{C}$; mobile phase, $\mathrm{MeOH}-\mathrm{H}_{2} \mathrm{O}$ (1:1); flow rate, $1.5 \mathrm{ml} / \mathrm{min}$; RI detector] to give $2(2.5 \mathrm{mg})$.

Erigerenone A (1): Colorless oil. $[\alpha]_{\mathrm{D}}^{24}+7.3^{\circ}(c=0.14, \mathrm{MeOH})$. UV $\lambda_{\max }$ $\mathrm{MeOH} n m(\log \varepsilon): 237$ (4.2). IR $v_{\max } \mathrm{CHCl}_{3} \mathrm{~cm}^{-1}: 1735,1691,1596$. HREI-MS m/z: $224.1063\left(\mathrm{M}^{+}\right.$, Calcd for $\left.\mathrm{C}_{12} \mathrm{H}_{16} \mathrm{O}_{4}: 224.1049\right) .{ }^{1} \mathrm{H}-\mathrm{NMR}$ $\left(600 \mathrm{MHz}, \mathrm{CDCl}_{3}\right)$ : see Table $1 .{ }^{13} \mathrm{C}-\mathrm{NMR}\left(150 \mathrm{MHz}, \mathrm{CDCl}_{3}\right)$ : see Table 2.

Erigerenone B (2): Colorless oil. $[\alpha]_{\mathrm{D}}^{26}+7.9^{\circ}(c=0.25, \mathrm{MeOH})$. UV $\lambda_{\max }$ $\mathrm{MeOH} \mathrm{nm}(\log \varepsilon): 238$ (4.1). IR $v_{\max } \mathrm{CHCl}_{3} \mathrm{~cm}^{-1}: 1735,1688,1593$. HREI-MS $m / z: 226.1178\left(\mathrm{M}^{+}\right.$, Calcd for $\left.\mathrm{C}_{12} \mathrm{H}_{18} \mathrm{O}_{4}: 226.1205\right)$. ${ }^{1} \mathrm{H}-\mathrm{NMR}$ (400 MHz, $\mathrm{CDCl}_{3}$ ): see Table 1. ${ }^{13} \mathrm{C}$-NMR $\left(100 \mathrm{MHz}, \mathrm{CDCl}_{3}\right)$ : see Table 2.

Erigerenone $\mathrm{C}(3)$ : Colorless oil. $[\alpha]_{\mathrm{D}}^{22}+4.2^{\circ}(c=0.24, \mathrm{MeOH})$. UV $\lambda_{\text {max }}$ $\mathrm{MeOH} \mathrm{nm}(\log \varepsilon): 279$ (3.8). IR $v_{\max } \mathrm{CHCl}_{3} \mathrm{~cm}^{-1}: 1731,1627,1592$. HREI-MS $m / z$ : $224.1055\left(\mathrm{M}^{+}\right.$, Calcd for $\left.\mathrm{C}_{12} \mathrm{H}_{16} \mathrm{O}_{4}: 224.1049\right)$. ${ }^{1} \mathrm{H}-\mathrm{NMR}$ $\left(400 \mathrm{MHz}, \mathrm{CDCl}_{3}\right)$ : see Table $1 .{ }^{13} \mathrm{C}-\mathrm{NMR}\left(100 \mathrm{MHz}, \mathrm{CDCl}_{3}\right)$ : see Table 2.

Acknowledgments We are grateful to Mr. S. Sato and Mr. T. Matsuki of this university for providing the mass and NMR spectra.

\section{References}

1) Hashidoko Y., Biosci. Biotech. Biochem., 59, 886-890 (1995).

2) Shanghai Scientific Technological Publishers and Shougakukan (eds.), "Dictionary of Chinese Materia Medica," Vol. 1, Shougakukan, Tokyo, 1985, p. 25.

3) Miyazawa M., Tokugawa M., Kameoka H., Agric. Biol. Chem., 45, 507-510 (1981).

4) Waddell T. G., Osborne C. B., Collison R., Levine M. J., Cross M. C., Silverton J. V., Falles H. M., Sokoloski E. A., J. Org. Chem., 48, $4450-4453$ (1983).

5) Jakupovic J., Chau-Thi T. N., Fischer N. H., Phytochemistry, 25, 1223-1224 (1986).

6) Iijima T., Yaoita Y., Kikuchi M., Nat. Med., 57, 75 (2003).

7) Iijima T., Yaoita Y., Kikuchi M., Chem. Pharm. Bull., 51, 545-549 (2003)

8) Iijima T., Yaoita Y., Kikuchi M., J. Tohoku Pharmaceutical University, "in press."

9) Cocu F. G., Wolczunowicz G., Bors L., Posternak T., Helv. Chim. Acta, 53, 739-749 (1970).

10) Che Y., Gloer J. B., Wicklow D. T., J. Nat. Prod., 65, 399-402 (2002).

11) Wolczunowicz G., Cocu F. G., Posternak T., Helv. Chim. Acta, 53, 2275-2288 (1970).

12) Kupchan S. M., Britton R. W., Ziegler M. F., Gilmore C. J., Restivo R. J., Bryan R. F., J. Am. Chem. Soc., 95, 1335-1336 (1973).

13) Joseph-Nathan P., Hernandez J. D., Roman L. U., Garcia G. E., Mendoza V., Mendoza S., Phytochemistry, 21, 1129-1132 (1982).

14) Oh H., Lee S., Lee H., Lee D., Lee S. Y., Chung H., Kim T. S., Kwon T., Phytochemistry, 61, 175-179 (2002). 